\title{
MOVING FROM COGNITIVE LOYALTY TO BEHAVIORAL LOYALTY THROUGH BRAND ROMANCE: EVIDENCE FROM HOTEL INDUSTRY OF IRAN
}

\author{
Amir KHAZAEI POOL ${ }^{\mathrm{a}}$, Farhad HANIFI ${ }^{\mathrm{b}}$, Vahid Reza MIRABI ${ }^{\mathrm{c}}$, \\ Mohammad Javad TAGHIPOURIAN ${ }^{\mathrm{d}}$
}

\begin{abstract}
${ }^{a}$ Department of management, Qeshm international branch, Islamic Azad University, Qeshm, Iran, e-mail: amir_khp29@yahoo.com

${ }^{\mathrm{b}}$ Department of management, Central Tehran branch, Islamic Azad University, Tehran, Iran, e-mail: Far.Hanifi@iauctb.ac.ir

${ }^{c}$ Department of management, Central Tehran branch, Islamic Azad University, Tehran, Iran, e-mail: vrmirabi@yahoo.com

${ }^{\mathrm{d} D e p a r t m e n t}$ of management, Chalous branch, Islamic Azad University, Chalous, Iran, e-mail: jpouryan@gmail.com
\end{abstract}

Cite this article: Khazei Pool, A., Hanifi, F., Mirabi, V. R., Taghipourian, M. J. (2018). Moving from Cognitive Loyalty to Behavioral Loyalty through Brand Romance: Evidence from Hotel Industry of Iran. Deturope, 10(2), 4-16.

\begin{abstract}
Brand romance is considered as a very important construct in marketing especially in brand area leading to the occurrence of some behaviors in consumers. However, a few types of research have been conducted on the importance of brand romance in hoteling. The present research aims to identify and test the effect of brand romance on four kinds of customer loyalty including cognitive loyalty, affective loyalty, conative loyalty and behavioral loyalty. The semi-structured interview was used to identify the measuring tool of brand romance. Then, customer loyalty questionnaire was added and distributed in the statistical society of the study. Data were tested using Smart-Pls2. Results of the research showed that brand romance had positive and significant effect on four kinds of loyalty. This research is a guide for hotel managers and marketers to perceive brand romance from viewpoints of customers. In addition, by applying suggestions, the research will help marketers create a stronger relationship between brand and customers and thus benefit from its outcomes.
\end{abstract}

Keywords: brand romance, cognitive, affective, conative, behavioral, loyalty

\section{INTRODUCTION}

In recent years, researchers have paid special attention to feelings of consumer (Holbrook and Hirschman, 1982). According to researches of Ascher (1999), human beings (consumers) are seeking romantic relationship. Romantic relationship is not limited to males and females rather it is available between human and object, images and ideas. Bowlby was the first person who did a research on attachment based on the relationship between parents and neonates $(1970,1980)$. Similarly, researches on marketing show that consumers can attach to brands (Schouten \& McAlexander, 1995). Such concept that reflects attachments and 
romantic dependencies has been studied in researches on behavior of consumer (i.e. Shimp \& Madden, 1988).

Fournier (1998) believed that consumers could make romantic relationships with brands and in some cases; such connections can be strong (Fournier, 1998). Brand romance is one of affective attachments that were presented by Patwardhan \& Balasubramanian (2011) and it includes three dimensions of pleasure, arousal and dominance. Although brand romance of products is increasing, it has been less paid attention in services' industry especially hoteling in Iran. The present research aims to identify this gap and to answer following question: what effect does the brand romance have on kinds of customer loyalty in hotels?

Concerning the importance of brand romance, marketers in services \& hoteling sector should perceive factors affecting brand romance. In products' sector, some researchers tried to do it. For example, Patwardhan \& Balasubramanian (2011) indicated that the consequences of brand romance were attitude towards brand as a determinant and brand loyalty. Other researchers such as Kruger et al (2013), Patwardhan (2004) and Petzer et al (2014) studied determinants and consequences of brand romance. Kruger et al (2013) revealed that there was a significant relationship between attitude towards brand, trust, loyalty and brand romance. Petzer et al (2014) found brand loyalty as the consequence of brand romance. Patwardhan (2004) indicated that subjective brand knowledge, brand novelty and brand satiety are background factors for brand romance. In hoteling sector in Iran, most researches addressed the effect of brand equity on satisfaction and loyalty of customer and other related constructs. Rahimnia, Najafi, and Alavi (2014) indicated that brand preference had significant effect on brand attachment in Homa hotel in Iran. Given the country's prospect of attracting 20 million tourists by 2025, competition in the hotel industry will increase sharply, as even foreign companies are planning to enter this area. Therefore, brand, branding, and then building an emotional relationship with the brand will be one of the requirements of Iranian hotels in the future.Therefore, the present research aims to study the effect of brand romance on four kinds of loyalty including cognitive loyalty, affective loyalty, conative loyalty and behavioral loyalty as consequences of brand romance and qualitative and quantitative approaches have been used. The structure of paper has been organized as follows: first, the literature is studied; the model and hypotheses are codified in addition to description of brand romance. Then, results and conclusion are discussed.

\section{Brand romance}

Brand romance is an introverted subjective state in response to the brand as a stimulant and it is identified by following factors: positive strong sense to a brand, high arousal created by the 
brand, tendency of the brand to dominance in cognitive mind of consumer (Patwardhan \& Balasubramanian, 2011). Brand romance is appeared when the individual has knowledge on features of the stimulants that have been evaluated positively and he/she perceive some novelty in them thus the individual is encouraged to approach the stimulant. If the novelty is not perceived and the knowledge on the stimulant has been evaluated poorly or negatively, the tendency to approach the stimulant may be reduced. When the individual is satisfied with the stimulant, perceived novelty will be reduced. The brand romance is existent in the individual. Different individuals may experience various levels of brand romance (Patwardhan et al, 2004) because brand romance is a concept specific to an object.

\section{Theoretical framework and hypotheses}

Kruger (2013) concluded in his research that brand romance had positive and significant relationship with behavioral and attitudinal loyalties. Cognitive loyalty is based on beliefs in brand (Kumar Roy et al, 2009). Affective loyalty shows the favorable level of attitude and liking of customer to a brand. On the other hand, affective loyalty refers to the amount of consumer's liking of brand (Kumar Roy et al, 2009). Conative loyalty means to create behavioral intentions for buying a product. Such loyalty has deeper commitment. In other words, it refers to the level of customer's commitment to continuous purchase of a product in future. Conative loyalty states that attitudinal loyalty should be followed by liking to do something such as rebuying a brand. Such loyalty is stronger than affective loyalty. Conative loyalty refers to an intense tendency to a brand loyalty (Oliver, 1999). Researchers who did research on brand loyalty believed that commitment to brand and complete loyalty to the brand required existence of an affective and romantic attachment between consumer and the brand (Patwardhan \& Balasubramanian, 2011; Oliver 1999). Therefore, concerning abovementioned, it can be assumed that:

Hypothesis 1: brand romance has a positive effect on cognitive loyalty.

Hypothesis 2: brand romance has a positive effect on affective loyalty.

Hypothesis 3: brand romance has a positive effect on conative loyalty.

Oliver (1999) stated that behavioral loyalty is a state in which behavioral intentions change into practice (Kumay Roy et al, 2009). If a person attaches romantically a brand, he/she will tend to pay extra money for that brand. For this purpose, the consumer tends intensely to buy the brand. If the consumer is fond of a brand, it will be expected that positive statements are stated about the brand (Sarkar, 2011). Therefore, it can be assumed that:

Hypothesis 4: brand romance has a positive effect on behavioral loyalty. 
Figure 1 Conceptual model of the study

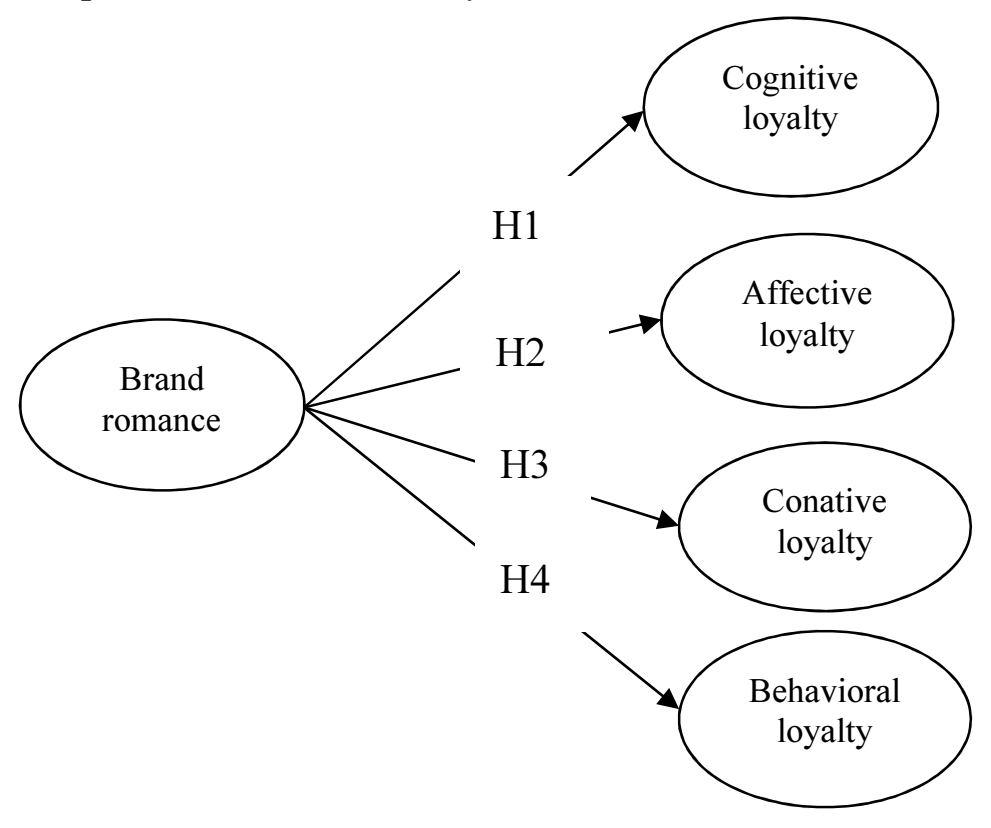

METHODS

In this research, 48 consumers above 18 years old (18 males and 30 females aged between 18 and 50 years old) were interviewed using inductive approach. The consumers were asked to name the brand which they are fond of it. Then, some questions were asked about the reasons why they are fond of the brand and other feelings. After deep interview and analysis of over 367 minutes of interviews with consumers, 117 items were obtained using open and axial coding (8 constructs including: connections, arousal, dominance, passion, liking, intimacy, pleasure and uniqueness). In the next stage, content validity of the questions was studied using 11 doctorate students of marketing (in form of proper and improper). Then, content validity index of Lawshe (Lawshe, 1975) was calculated for each item (based on Lawshe table, optimal threshold amount for eleven specialists is 0.59). As a result, items in which Lawshe amount is lower than optimal threshold were removed and number of items was reduced to 80 ones. Concerning that such items have been specific to brands of products, to match items with service \& hoteling sector, Lawshe index was used again to identify items appropriate for hoteling sector using the same specialists. As a result, 26 items were removed and 54 items remained to measure brand romance with a five point scale ranging from 1 (strongly disagree) to 5 (strongly agree). Then, questions related to four loyalties (YeboahAsiamah, Quaye, \& Nimako, 2016) were added and the questionnaire was distributed in the population under study and it was analyzed by Smart-PLS 2. Statistical population of the research is 4 and 5 star hotels in Mazandaran province-north of Iran because the brand is more tangible in such hotels. Concerning statistics obtained from cultural heritage \& tourism organization of Mazandaran province, it was found that six 4-star hotels and one 5-star hotel were running in 2014 in the province. The 4-star hotels were Badleh, Salardareh and Navid 
located as Sari, Narenjestan-e Noor and Parsian Khazar located at Chalous, Parsian Azadi (old) in Ramsar and Parsian Azadi Khazar (new) located at Ramsar was the 5-star hotel. Members of statistical population were customers of the hotels. To determine sample size, Krejcie-Morgan table was used thus 384 persons were chosen out of over 10000 persons. Therefore, 387 questionnaires were distributed in seven hotels based on random sampling and data were gathered.

\section{DATA ANALYSIS AND RESULTS}

\section{Demographic analysis}

Demographic features of the research showed that $34.8 \%$ of respondents were women and $65.2 \%$ were men. $21.6 \%$ of population under study were below 30 years old, $41.7 \%$ were between 30 and 50 years old, $36.7 \%$ were above 50 years old. Regarding education, $29.2 \%$ of people had bachelor or lower, $57 \%$ had master degree and $13.8 \%$ had doctorate degree.

\section{Analysis of hypotheses/Evaluation of the measuring model}

To test hypotheses, the external model should be evaluated. To study fitness of the measuring model, convergent validity and reliability were used. To measure convergent validity, factor loading and average variance extracted (AVE) were used. The result of factor loading of questions has been shown in Tab. 1.

Table 1 Confirmatory analysis of measurement model

\begin{tabular}{|l|l|l|}
\hline Factors & Items & $\begin{array}{l}\text { Factor } \\
\text { loading } \\
\text { (FL) }\end{array}$ \\
\hline \multirow{5}{*}{ Connection } & I feel happy for being interested in this brand. & 0.522 \\
\cline { 2 - 3 } & When I use this brand, I feel comfortable and relax. & 0.626 \\
\cline { 2 - 3 } & $\begin{array}{l}\text { I try to increase my information about this brand to be able to defend } \\
\text { this brand adequately if needed. }\end{array}$ & 0.680 \\
\cline { 2 - 3 } & This brand enhances my personality. & 0.687 \\
\cline { 2 - 3 } & I am dependent to this brand because I use it for long time. & 0.635 \\
\hline & $\begin{array}{l}\text { When I see this brand's advertising, I am encouraged to buy this } \\
\text { brand's products. }\end{array}$ & 0.203 \\
\cline { 2 - 3 } & When I see this brand's advertising, I feel I made the right choice. & 0.695 \\
\cline { 2 - 3 } & $\begin{array}{l}\text { When I see this brand's advertising, if someone was near me I will } \\
\text { admire this brand. }\end{array}$ & 0.618 \\
\cline { 2 - 3 } & This brand is the only brand that has attracted me. & 0.744 \\
\cline { 2 - 3 } & When I see this brand's advertising, my desire increase to attain it. & 0.770 \\
\cline { 2 - 3 } & $\begin{array}{l}\text { If I see the advertising of this brand's new product or service, I will } \\
\text { follow it to attain more information. }\end{array}$ & 0.693 \\
\cline { 2 - 3 } & $\begin{array}{l}\text { Good quality of this brand's services will make me to purchase of it } \\
\text { in next purchases. }\end{array}$ & 0.700 \\
\cline { 2 - 3 } & $\begin{array}{l}\text { When I see this brand's advertising, I feel good because I have or use } \\
\text { its service or product. }\end{array}$ & 0.717 \\
\hline
\end{tabular}


Table 1 (continued)

\begin{tabular}{|c|c|c|}
\hline \multirow[t]{3}{*}{ Dominance } & This brand is important and effective in everyday life of people. & 0.702 \\
\hline & I always have a whim to use this brand's product and services. & 0.742 \\
\hline & When not use this brand for some day, it is always in my mind. & 0.637 \\
\hline \multirow[t]{6}{*}{ Passion } & Because of my interest in this brand, I am its fan. & 0.777 \\
\hline & When I see this brand, I start to admire it. & 0.808 \\
\hline & This brand is so attractive. & 0.360 \\
\hline & I prefer this brand to others. & 0.393 \\
\hline & $\begin{array}{l}\text { When using this brand I feel there are lots of unknown things about it } \\
\text { that make me to reach them. }\end{array}$ & 0.347 \\
\hline & $\begin{array}{l}\text { If this brand is absent, I am forced to move to other brands, but I do } \\
\text { not feel good. }\end{array}$ & 0.662 \\
\hline \multirow[t]{16}{*}{ Liking } & I have a particular interest in this brand & 0.701 \\
\hline & When others say something bad about this brand, I ask the reason & 0.549 \\
\hline & $\begin{array}{l}\text { If this brand was absent or unavailable in market, it is difficult to get } \\
\text { used to others. }\end{array}$ & 0.822 \\
\hline & $\begin{array}{l}\text { If this brand was absent or unavailable in market, it is difficult to } \\
\text { choose others. }\end{array}$ & 0.765 \\
\hline & $\begin{array}{l}\text { If this brand was absent or unavailable in market, I cannot choose the } \\
\text { right alternative. }\end{array}$ & 0.834 \\
\hline & If I don't have this brand I feel dissatisfied. & 0.815 \\
\hline & If I don't have this brand I feel worry. & 0.791 \\
\hline & If this brand was unavailable, I feel sad. & 0.698 \\
\hline & $\begin{array}{l}\text { If in a meeting, people speak about this brand I will encourage them } \\
\text { to buy this brand. }\end{array}$ & 0.772 \\
\hline & If someone does not like this brand I would again insist on this brand. & 0.635 \\
\hline & $\begin{array}{l}\text { When I see this brand or its advertising, I feel happy because it is still } \\
\text { popular and is available in market. }\end{array}$ & 0.789 \\
\hline & $\begin{array}{l}\text { If this brand was unavailable, I feel that other brands cannot satisfy } \\
\text { my need and feel sorry. }\end{array}$ & 0.672 \\
\hline & This brand is my first choice. & 0.092 \\
\hline & $\begin{array}{l}\text { When I want to purchase something new, this brand is my first } \\
\text { choice. }\end{array}$ & 0.376 \\
\hline & I have no bias to this brand. & 0.408 \\
\hline & It does not matter this brand was available or not. & 0.542 \\
\hline \multirow[t]{2}{*}{ Intimacy } & $\begin{array}{l}\text { In a meeting when people speak about this brand, I try to say my } \\
\text { usage experience of it. }\end{array}$ & 0.319 \\
\hline & If this brand was absent in market, its absence may be feel. & 0.979 \\
\hline \multirow[t]{9}{*}{ Pleasure } & This brand quality is high & 0.599 \\
\hline & I am satisfied when I use this brand & 0.083 \\
\hline & I feel good when using this brand & 0.551 \\
\hline & $\begin{array}{l}\text { I feel happy when I see this brand's advertising have this brand } \\
\text { because I have it. }\end{array}$ & 0.149 \\
\hline & When I use this brand, I feel happy: my choice is not wrong & 0.703 \\
\hline & I feel good when using this brand because it has what I want & 0.737 \\
\hline & When I see this brand I feel passionate. & 0.731 \\
\hline & $\begin{array}{l}\text { I have tried other brands, but I am not satisfied; this brand, however, } \\
\text { has been very good }\end{array}$ & 0.696 \\
\hline & When I use this brand I feel proud of it. & 0.748 \\
\hline
\end{tabular}


Table 1 (continued)

\begin{tabular}{|l|l|l|}
\hline Uniqueness & This brand is very unique & 0.899 \\
\cline { 2 - 3 } & Everybody cannot provide this brand. & 0.304 \\
\cline { 2 - 3 } & This is a very special brand. & 0.227 \\
\cline { 2 - 3 } & This brand gives me special beauty. & 0.248 \\
\cline { 2 - 3 } & When I use this brand, I feel superior to other brands. & 0.865 \\
\hline
\end{tabular}

As seen in Tab. 1 in which results of confirmatory factor analysis have been shown for measuring convergent validity, factor loading of some questions is lower than optimal threshold of 0.3 thus it was removed and the model was reevaluated. As a result, after two stages of confirmatory factor analysis, 13 items were removed (out of 54 items) and 41 items remained and their factor loading is above optimal threshold. Therefore, the analysis continued. In addition, concerning the amount of average variance extracted (AVE) which is above 0.5 , it can be stated that items can illustrate sufficiently variance of research variables. Composite reliability and Cronbach' alpha of variables are above 0.7 which are shown in Tab. 2. Thus, these criteria confirm proper fitness of the model. The final scale items are shown in Appendix.

Table 2 Reliability and validity of measurement model

\begin{tabular}{|l|l|l|l|}
\hline factors & AVE & Cronbakh Alfa & CR \\
\hline Connection & 0.527 & 0.751 & 0.724 \\
\hline Arousal & 0.518 & 0.882 & 0.882 \\
\hline Dominance & 0.689 & 0.765 & 0.739 \\
\hline Passion & 0.638 & 0.714 & 0.840 \\
\hline Liking & 0.500 & 0.918 & 0.930 \\
\hline Intimacy & 1.000 & 1.000 & 1.000 \\
\hline Pleasure & 0.577 & 0.818 & 0.863 \\
\hline Uniqueness & 0.808 & 0.764 & 0.894 \\
\hline
\end{tabular}

\section{Internal or structural model}

After testing external model, it is necessary to present internal model that shows the relation between research variables. The research hypotheses can be studied using internal model. Furthermore, before testing hypothesis, it is better to evaluate quality of internal or structural model. The quality of structural model means whether independent variables are able to predict dependent variables. In this case, construct cross validated redundancy called Q2 factor is used. If Q2 is positive, it can be concluded that structural model has a proper quality. 
Table 3 Quality of internal or structural model

\begin{tabular}{|c|c|c|c|}
\hline Total & SSO & SSE & 1-SSE/SSO (Q2) \\
\hline Affective & 1161.000000 & 717.247824 & 0.382215 \\
\hline Behavioral & 1161.000000 & 870.740688 & 0.250008 \\
\hline Cognitive & 1548.000000 & 1015.855430 & 0.343763 \\
\hline Conative & 774.000000 & 533.410658 & 0.310839 \\
\hline
\end{tabular}

Concerning above table, since Q2 is positive, it can be concluded that structural model has a proper quality showing strong predictive power of the model about introverted construct and proper fitness of the structural model is confirmed. After fitting the measuring and structural models based on data analysis algorithm in PLS, the researcher is allowed to study research hypotheses and results.

Figure 2 General model of research (t-value)

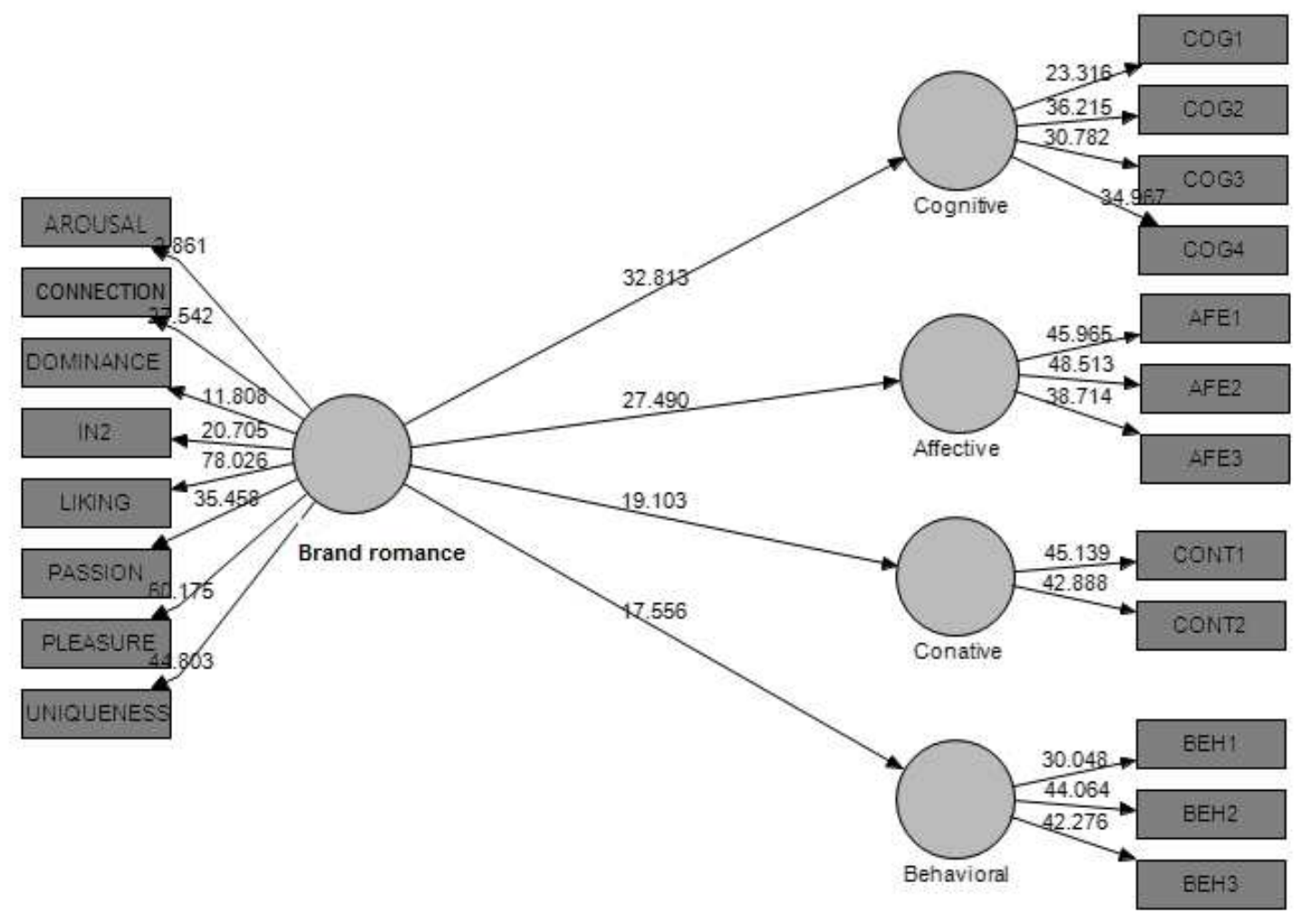

To study significance level of the path factor, it is necessary to show t-value of each path. Tvalue of the test has been shown in Fig. 2. The coefficients should be above 1.96 to confirm their significance in confidence level of $95 \%$. Summary of results has been shown in table 4 . 
Table 4 Path coefficients and testing results

\begin{tabular}{|l|l|l|l|}
\hline \multicolumn{1}{|c|}{ Path } & path coefficient & t value & result \\
\hline brand romance $\longrightarrow$ cognitive loyalty & 0.759 & 32.813 & confirmed \\
\hline brand romance $\longrightarrow$ affective loyalty & 0.733 & 27.490 & confirmed \\
\hline brand romance $\longrightarrow$ conative loyalty & 0.653 & 19.103 & confirmed \\
\hline brand romance $\longrightarrow$ behavioral loyalty & 0.612 & 17.556 & confirmed \\
\hline
\end{tabular}

Tab. 4 shows results of hypotheses in form of path coefficients with significance level related to research hypotheses. As seen in Tab. 4, the first hypothesis, the effect of brand romance on cognitive loyalty, is confirmed because path significant factor of these variables is 32.813 which is higher than 1.96 showing significant effect of brand romance on cognitive loyalty in confidence level of $95 \%$. Thus, the hypothesis is confirmed. In other words, $75 \%$ of changes in cognitive loyalty are due to brand romance.

Significance coefficient of the effect of brand romance on affective loyalty is higher than optimal threshold (27.490). Therefore, such effect is significant and the hypothesis is confirmed. Since the path coefficient is positive, the effect is positive and significant and the size effect is 0.73 . Therefore, the second hypothesis is confirmed.

Concerning significance coefficient of the effect of brand romance on conative loyalty (higher than optimal threshold (19.103)), such effect is significant. Since the path coefficient is positive, the effect is positive and significant. Therefore, it can be said that $65 \%$ of changes in conative loyalty are due to brand romance. As a result, the third hypothesis is confirmed.

Significance coefficient of the effect of brand romance on affective loyalty is higher than optimal threshold (17.556). Therefore, such effect is significant and the hypothesis is confirmed. Since the path coefficient is positive, the effect is positive and significant thus the effect size is 0.61 . Therefore, the fourth hypothesis is confirmed.

\section{DISCUSSION, COMPARISON AND CONCLUSION}

The paper studied the effect of brand romance on customer loyalty in 4 and 5 star hotels of Mazandaran and a scale was presented. 4 and 5 star hotels were chosen because brand is more tangible in such hotels. First, a scale was prepared to measure brand romance by interviewing with consumers of goods. Then, opinions of experts were obtained to proportionate the scale with hotel and services. Consequently, confirmatory factor analysis was done on it and the effect of brand romance on four types of loyalty was tested. Generally, there is no discussion 
and comparison for this subject because there is no literature about this area. But few foreign researches have been identified in this regard (Kruger et al, 2013; Patwardhan, 2004; Petzer et al, 2014) and results of the present research are consistent with their results. Results of current research proved that a brand romance between customers of the hotels and their brands may be significantly effective on customers' loyalties. Oliver (1999) identified four areas of loyalty. The first area is about the belief and cognition of customers. Being involved in belief and cognition of the customer and being the first rank in mind of the customer are important and critical points and it is recognized as the first stage of loyalty. Result of the research indicated that if brand romance was created in hotels, it could be effective on belief and cognition of hotel customers and it could remain in minds of customers. The name of hotel will be recorded in the mind of customer as the first brand. The second area is the sense and liking of customer to the brand. Affective loyalty is amount of liking of consumer to the brand (Kumar Roy et al, 2009). The result indicated that creation of brand romance between customers and hotels could lead to liking in long term. The third area is conative loyalty which is stronger than affective loyalty. Frequent reception of defective goods will reduce conative loyalty (Oliver, 1999). The fourth area is behavioral loyalty. It is a state by which behavioral intentions will change into practice (Kumar Roy et al, 2009). Results of the research showed that the romance between customers and brand of hotels could lead to attitudinal loyalty (cognitive, affective and conative loyalties) and such attitude could change into the practice as well thus behavioral loyalty was created in customers meaning purchase and revisit of hotel, introducing the hotel to friends, relatives, positive statements about the hotel. Therefore, concerning research results, followings can be suggested to the hotels:

1- The hotel managers should pay attention to brand and branding and brand identity

2- Determination of the level and amount of brand romance in hotels of Mazandaran for future measures. If amount of brand romance is low in hotels, it should be increased.

3- Concerning that brand romance is the most effective on cognitive loyalty, hotel managers should focus on this area and they should keep the name of brand (as a first place) in minds of customer and some measures should be taken to reach this goal.

4- Results of the research showed that brand romance is more effective on attitudinal loyalty of customers than behavioral loyalty. Therefore, it is necessary to take some measures in this direction such as making customers pleasant when using services and providing unique services in hotels. 
The nature of the research and sample size may cause some problems for generalization of results. In addition, samples affected by the culture may cause similar problems. Another step in this direction is that backgrounds and consequences of brand romance are identified in hotels of the province then they are studied quantitatively. Quantitative research may show more issues such as the effect of identified factors and factors affecting brand romance. For example, service features have many dimensions and the most important dimensions can be identified as backgrounds.

\section{REFERENCES}

Ascher B. (1999), Dancing in the Dark: Romance, Yearning and the Search for the Sublime, Harper Collins Publishers Inc. N.Y. N.Y.

Fournier, S. (1998). Consumers and their brands: Developing relationship theory in consumer research. Journal of consumer research, 24(4), 343-373.

Holbrook, M. B., \& Hirschman, E. C. (1982). The experiential aspects of consumption: Consumer fantasies, feelings, and fun. Journal of consumer research, 9(2), 132-140.

Kruger, L. M., Kuhn, S. W., Petzer, D. J., \& Mostert, P. G. (2013). Investigating brand romance, brand attitude and brand loyalty in the cellphone industry: original research. Acta Commercii, 13(1), 1-10.

Kumar Roy, S., Butaney, G., \& Bhutaney, B. (2009). Examining the effects of the customer loyalty states on the word of mouth. PACIS 2009 Proceedings, 85.

Lawshe, C. H. (1975). A quantitative approach to content validity. Personnel psychology, 28(4), 563-575.

Oliver, R. L. (1999). Whence consumer loyalty?. Journal of Marketing, 63, 33-44.

Patwardhan, H., \& Balasubramanian, S. K. (2011). Brand romance: a complementary approach to explain emotional attachment toward brands. Journal of Product \& Brand Management, 20(4), 297-308.

Patwardhan, H. (2004). The romance of brands: An interpersonal relationship approach to assess the antecedents and consequence of consumer attachment to the brand (Doctoral Dissertation), Southern Illinois University

Petzer, D., Mostert, P., Kruger, L-M. and Kuhn, S. (2014). The dimensios of brand romance as predictors of brand loyalty among cell phone users, South African Journal of Economic and Management Sciences, 17(4), 457-470

Rahimnia, F., Najafi, M., \& Alavi, M. (2014). Brand audit and investigating the relationship between audit indicators in hospitality industry (A case of study: Shiraz Homa Hotel), New Marketing Research, 3(4), In Persian.

Sarkar, A. (2011). Romancing with a brand: A conceptual analysis of romantic consumerbrand relationship. Management \& Marketing, 6(1), 79-94.

Schouten, J. W., \& McAlexander, J. H. (1995). Subcultures of consumption: An ethnography of the new bikers. Journal of consumer research, 22(1), 43-61.

Shimp, T. A., \& Madden, T. J. (1988). Consumer-object relations: A conceptual framework based analogously on Sternberg's triangular theory of love. NA-Advances in Consumer Research, 15, 163-168

Yeboah-Asiamah, E., Quaye, D. M., \& Nimako, S. G. (2016). The effects of lucky draw sales promotion on brand loyalty in mobile telecommunication industry. African Journal of Economic and Management Studies, 7(1), 109-123. 


\section{Appendix}

\section{Connection}

I feel happy for being interested in this brand.

When I use this brand, I feel comfortable and relax.

I try to increase my information about this brand to be able to defend this brand adequately if needed.

This brand enhances my personality.

I am dependent to this brand because I use it for long time.

Arousal

When I see this brand's advertising, I am encouraged to buy this brand's products.

When I see this brand's advertising, I feel I made the right choice.

When I see this brand's advertising, if someone was near me I will admire this brand.

This brand is the only brand that has attracted me.

When I see this brand's advertising, my desire increase to attain it.

If I see the advertising of this brand's new product or service, I will follow it to attain more information.

Good quality of this brand's services will make me to purchase of it in next purchases.

When I see this brand's advertising, I feel good because I have or use its service or product.

\section{Dominance}

This brand is important and effective in everyday life of people.

I always have a whim to use this brand's product and services.

When not use this brand for some day, it is always in my mind.

\section{Passion}

Because of my interest in this brand, I am its fan.

When I see this brand, I start to admire it.

This brand is so attractive.

I prefer this brand to others.

When using this brand I feel there are lots of unknown things about it that make me to reach them.

If this brand is absent, I am forced to move to other brands, but I do not feel good.

\section{Liking}

I have a particular interest in this brand

When others say something bad about this brand, I ask the reason

If this brand was absent or unavailable in market, it is difficult to get used to others.

If this brand was absent or unavailable in market, it is difficult to choose others.

If this brand was absent or unavailable in market, I cannot choose the right alternative.

If I don't have this brand I feel dissatisfied.

If I don't have this brand I feel worry.

If this brand was unavailable, I feel sad.

If in a meeting, people speak about this brand I will encourage them to buy this brand.

If someone does not like this brand I would again insist on this brand.

When I see this brand or its advertising, I feel happy because it is still popular and is available in market.

If this brand was unavailable, I feel that other brands cannot satisfy my need and feel sorry.

This brand is my first choice.

When I want to purchase something new, this brand is my first choice.

I have no bias to this brand.

It does not matter this brand was available or not. 


\section{Intimacy}

In a meeting when people speak about this brand, I try to say my usage experience of it. If this brand was absent in market, its absence may be feel.

\section{Pleasure}

This brand quality is high

I am satisfied when I use this brand

I feel good when using this brand

I feel happy when I see this brand's advertising have this brand because I have it.

When I use this brand, I feel happy: my choice is not wrong I feel good when using this brand because it has what I want When I see this brand I feel passionate.

I have tried other brands, but I am not satisfied; this brand, however, has been very good When I use this brand I feel proud of it.

\section{Uniqueness}

This brand is very unique

Everybody cannot provide this brand.

This is a very special brand.

This brand gives me special beauty.

When I use this brand, I feel superior to other brands. 